\title{
Impact of Biochar on Growth, Biochemical Parameters and Nutrients Content of Volkamer Lemon ( $C$. volkameriana, Tenx pasq.) under Saline Condition
}

\author{
A. M. Abo-Ogiala, \\ Horticulture Department, Faculty of Agriculture, Tanta University, 31527 Tanta, Egypt.
}

\begin{abstract}
$\mathbf{N}$ EW strategies for plant adaptation with soil affected by salinity are needed. Recent studies on different crops introduced biochar as a promising soil amendment that ameliorate problems associated with salinity stress. Here the study proof that biochar helps seedlings of Volkamer lemon (C. volkameriana, Tenx pasq.) copping with salt stress. Uniform three months old seedlings were transferred in a mixture media consists of sand: peat moss: biochar, 4: 2: 0.5 or $1 \mathrm{v} / \mathrm{v}$, respectively. The plants were subjected to 0,100 and $200 \mathrm{mM} \mathrm{NaCl}$. The performance were determined by growths related to fresh (F.W)and dry mass (D.W), leaf area, shoot and root length, shoot diameter and root width, shoot/root and water content. Electrical conductivity (EC), Relative chlorophyll content (RCC) and proline content as biochemical parameters were measured. The elements of $\mathrm{N}, \mathrm{P}, \mathrm{K}^{+}, \mathrm{Na}^{+}$and $\mathrm{K}^{+} / \mathrm{Na}^{+}$ratio were looked up. The results indicated that biochar decreased the salinity effect on plant performance. Plants grown under salt stress in a mixture media contained biochar showed higher content of chlorophyll, $\mathrm{N}, \mathrm{P}$ and $\mathrm{K}^{+}$but showed lower content of shoot/root, $\mathrm{K}^{+} / \mathrm{Na}^{+}$, proline, $\mathrm{EC}$ and $\mathrm{Na}^{+}$than those grown in the media free of biochar. These results supported the views that introduce biochar as a promising application in mitigating the negative effects of salinity stress on volkamer lemon seedlings.
\end{abstract}

Keywords: Salt stress, Biochar, Volkamer lemon, Chlorophyll, Proline, Electrical Conductivity.

\section{Introduction}

Production of citrus fruits is one of the most agriculture economic goals in many areas worldwide. The main regions of citrus cultivation are having arid and semi-arid climates (Davies \& Albrigo, 1999 and Lindaya 2008). In such condition where high temperature and dry atmosphere together with water restrictions result in increasing salinity accumulation, subsequently leads to growth reduction and impair crop production (Yadav et al., 2011). In order to cultivate citrus in such area it is necessary to select genotypes that show salt tolerance (BRITO et al., 2014 and Najafian et al., 2008). Citrus species have shown different strategies for coping with salinity (Abadi et al., 2010, Brito et al., 2016 and Ruiz et al., 1997). In the same line, it is well known that rootstock is the main formation in citrus cropping system which plays a critical role in salt tolerance (Hepaksoy, 2000). Volkamer lemon is the most recommended citrus rootstock for citrus plantation because of the positive traits that are induced on the grafted scion. However, recent studies showed that volkamer lemon a salt susceptible rootstock (Fadli et al., 2015, Lea-Cox and Syvertsen, 1993).

Biochar is a pyrolysis of biomass (such as organic waste, manure, crop residues) which is produced under oxygen-limited conditions (Lehmann and Joseph, 2009). Van Zwieten et al. (2010) showed that application of biochar on its own resulted in slightly increasing surface area, $\mathrm{N}$ uptake and biomass production in wheat, soybean and radish. Only very little studies investigated the biochar application effect on woody plant species in general. Biochar application in agroforestry was found to bring clear benefits like soil fertility enhancement, increasing plant growth, increasing soil carbon sequestration, and impairing gas emissions (Stavi and Lal, 2013). Wood charcoal application with other combinations reflected a beneficial effect on tea plants, citrus, and vegetables (Ishigaki et al., 1990). Application of biochar improved leaf area and biomass productivity of 
Prunella vulgaris and Abutilon theophrasti under salt stress (Thomas et al., 2013). Adding Biochar to soils improved nitrogen and phosphorous uptake (Atkinson et al., 2010, Barrow 2012 and Joseph et al., 2010). Dharmakeerthi et al. (2012) reported that adding biochar to the nursery media of Hevea brasiliensis increased the uptake of nutrients and plant growth. Mixing biochar in culture pot media led to the increase in sugarcane root properties and the uptake of phosphorus and potassium (Yang et al., 2015). Drake et al. (2016) found that adding biochar to saline soil increased plant height and $\mathrm{K}^{+}$uptake while it decreased $\mathrm{Na}^{+}$uptake by Eucalyptus viminalis and Acacia mearnsii seedlings. Razaq et al. (2017) fount that biochar application in the field nursery of Acer mono leads to the increase in seedlings root length and width and general root system morphological features. From a fore mentioned overview, it is logical to predict the positive role of biochar effect in plant behavior under saline conditions. Therefore, the aim of the present investigation is to figure out the adaptive mechanism of biochar that ameliorate salinity stress on volkamer lemon seedlings.

\section{Material and Methods}

The study was started March and finished in June (90 days) 2012 and were repeated in 2013 in the greenhouse of Faculty of Agriculture, Tanta University. The experiment was laid out in a complete randomized block design with two factors and six replicates used for each treatment. The first factor was Biochar of wood chip that added instead of perlite to the recommended culture media of Naver et al. (1986).

\section{Preparation of biochar}

Wood sawdust was a source of biochar which prepared by slow pyrolysis in a kiln with a retention time of $2 \mathrm{~h}$. After overnight cooling, biochar gently crushed and ground to pass through a $0.5 \mathrm{~mm}$ sieve before use. Table 1 shows the characteristics of biochar used.

Biochar was added in three levels, i.e. 0, 0.5 and $1 \mathrm{v} / \mathrm{v}$, subsequently the mixture culture media consists of sand: peat moss: biochar, 4: 2: 0.5 or $1 \mathrm{v} / \mathrm{v}$, respectively. The second factor was salinization with three levels, i.e. 0,100 and $200 \mathrm{mM} \mathrm{NaCl}$. Uniform three months old seedlings were transferred to the previous media which was filled in black plastic bags (size, $7.5 \mathrm{~cm}$ wide $\mathrm{x} 18 \mathrm{~cm}$ height) with draining perforation. Bags arranged in rows inside the greenhouse at day/night temperatures of $\left(30 / 25 \pm 4^{\circ} \mathrm{C}\right)$, relative humidity between 55 $75 \%$ and $16 \mathrm{~h}$ photoperiod. To guarantee seedlings adaptation to salt stress and avoid osmotic shock, $\mathrm{NaCl}$ was added stepwise through one week to the final concentration of 100 and $200 \mathrm{mM} \mathrm{NaCl}$. To ensure sufficient available water for the native plants, media was kept at field capacity of $60 \%$ by adding suitable amount of water with or without $\mathrm{NaCl}$ every two days (Weggler et al., 2008). Foliar application using NPK nutrients at $20 \%$ concentration of each was used twice a week.

\section{Assessment of seedlings performance}

Three seedlings from each treatment were taken for plant performance assessment. Fresh weight of the whole seedling was measured. The different parts of each plant (leaves, stem and roots) were separated. Roots were washed to be free of culture media with tap water and then root length was measured. Stem length $(\mathrm{cm})$ from the surface of the media to the highest growing point, shoot/root length and leaf area $\left(\mathrm{cm}^{2}\right)$ per plant were also measured. Leaf area was calculated from the mean of three independent measurements in three different plants using $\mathrm{Cl} 203$ laser area meter (CID Bio-science Instrument, USA). Then all parts were washed with distilled water and dried for $72 \mathrm{~h}$ at $70^{\circ} \mathrm{C}$ for dry weight determination. Leave samples were milled after drying and stored for the following chemical analyses.

\section{Chemical characteristics}

The Micro Kjeldahl method (Page, 1982) was used for total Nitrogen $(\mathrm{N})$ determination. Total Phosphorus (P) was determined colorimetrically according to Cotteine et al. (1982). Potassium (K) and $(\mathrm{Na})$ were determined by flame photometer according to Jackson (1958). The proline content was determined as described by Monneveux

TABLE 1. Characteristics of biochar used in this study.

\begin{tabular}{|c|c|c|c|c|c|c|c|c|c|}
\hline Prosperities & $\begin{array}{c}\text { pH } \\
(1: 10)\end{array}$ & $\begin{array}{c}\text { EC } \\
(1: 10)\end{array}$ & $\begin{array}{c}\text { CEC } \\
(\mathrm{c} \mathrm{mol} \mathrm{kg-1)}\end{array}$ & $\begin{array}{c}\text { BD } \\
\left(\mathrm{g} \mathrm{cm}^{-3}\right)\end{array}$ & $\begin{array}{l}\text { Total } \\
\text { N (\%) }\end{array}$ & $\begin{array}{l}\text { Total } \\
\text { P (\%) }\end{array}$ & $\begin{array}{l}\text { Total } \\
\text { K(\%) }\end{array}$ & $\begin{array}{l}\mathrm{C} \\
(\%)\end{array}$ & $\begin{array}{l}\mathrm{C}: \mathrm{N} \\
\text { ratio }\end{array}$ \\
\hline After pyrolysis & 8.64 & 2.15 & 31.6 & 0.30 & 1.96 & 0.122 & 0.952 & 65.2 & 31.03 \\
\hline
\end{tabular}

Egypt. J. Hort. Vol. 45, No. 2 (2018) 
and Nemmar (1986). Electrolyte conductivity (EC) was determined as an indicator to Ion leakage according Tripathy et al. (2000). Relative chlorophyll contents (RCC) as spot values were recorded using SPAD chlorophyll Meter (Hansatech Instrument Ltd.,King' s Lynn,UK). The idea of chlorophyll Meter was to measure chlorophyll content by the quantification of green color intensity. The green color intensity readings were taken for leaf at the fourth internodes from the shoot tip. Three readings were made on each leaf and the arithmetic mean was calculated.

\section{Statistical analyses}

The mean of both seasons were statistically performed by Statistical Graphics Corporation, STATGRAPHICS Plus (St. Louis, MO, USA) for two way analysis of variance and employing Duncan's multiple range tests at the 0.05 confidence level.

\section{Results}

\section{Seedling performance}

Leaf areas of the volkamer lemon seedlings were significantly reduced in response to salt concentrations, 100 and $200 \mathrm{mM} \mathrm{NaCl}$ comparable with the control (Fig. 1, A). Both rates of biochar (char1 and char 2) showed better leaf area compared to control (Fig. 1, A). Furthermore, the reduction of leaf area in response to salt exposure was not significant after adding biochar (Fig. 1, B). Seedlings grown under salinity stress exhibited drastic reduction in fresh and dry mass compared to control (Fig. 2. A, B). Although all salt exposed plants that grown in free biochar medium showed significant reduction in fresh and dry mass than those grown in biochar applications (Fig. 2. A, B).

Moreover, plants showed significant increment in dry/fresh mass ratio by biochar treatments under both salt levels in comparison with control (Fig.2.C). Leaf water content is another sign of plants to be affected by salinity which was found to be decreased by raising salinity and this is in accordance with Navarro et al. (2010). As expected reduction of plant water content was clearly shown by increasing salinity (Fig. 2, D). Interestingly, adding of biochar significantly decreased the reduction in water content in response to salinity (Fig. 2, D). Further screening of salt responses of volkamer lemon seedlings, shoot length showed significant impaired growth at both salt levels compared to control (Fig. 3. A). Whereas biochar addition significantly reduced the influence on shoot length and diameter related to salt exposure (Fig. 3. A).
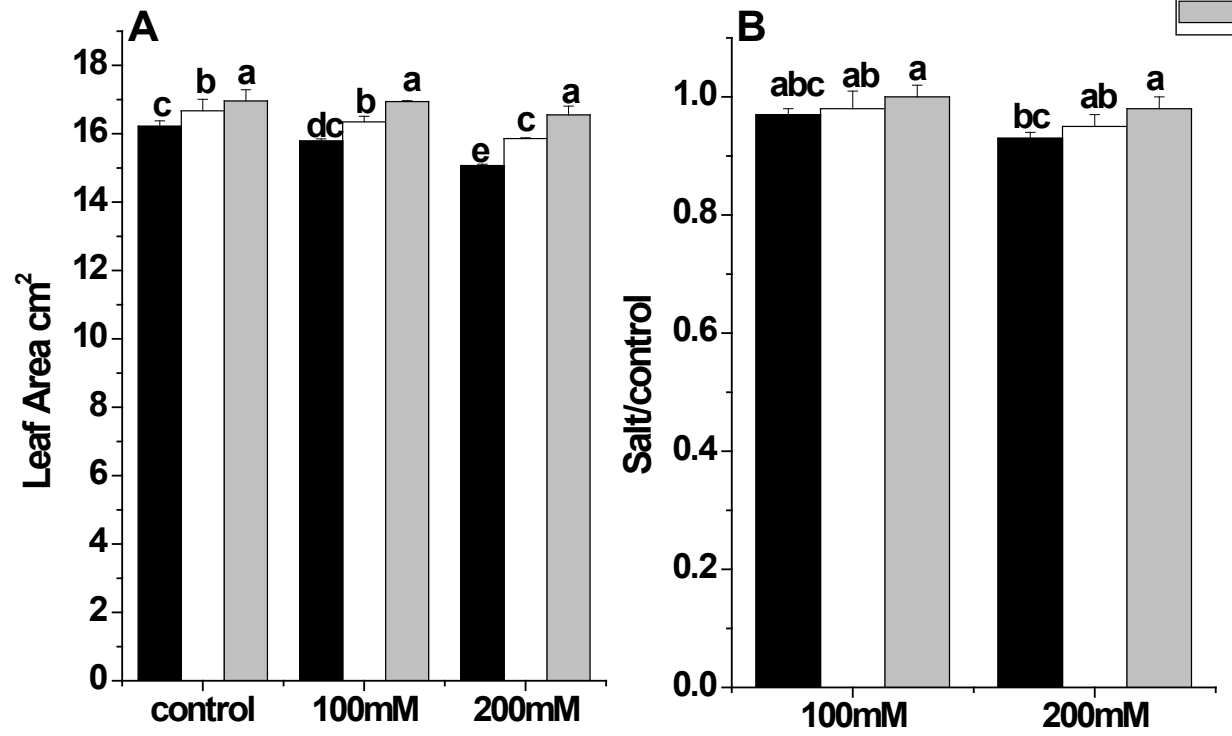

Fig. 1. A is showing the leaf area of volkamer lemon seedlings treated with 0,100 and $200 \mathrm{mM}$ of $\mathrm{NaCl}$ exposure for 90 days. B refers to salt: control ratio of the leaf area for the same data. Control, char 1 and char 2 refer to $0,0.5$ and 1 biochar concentration, respectively. Data indicated means $(n=5 \pm \mathrm{SE})$. Different letters indicated significant differences at $\mathbf{p}<\mathbf{0 . 0 5}$. 

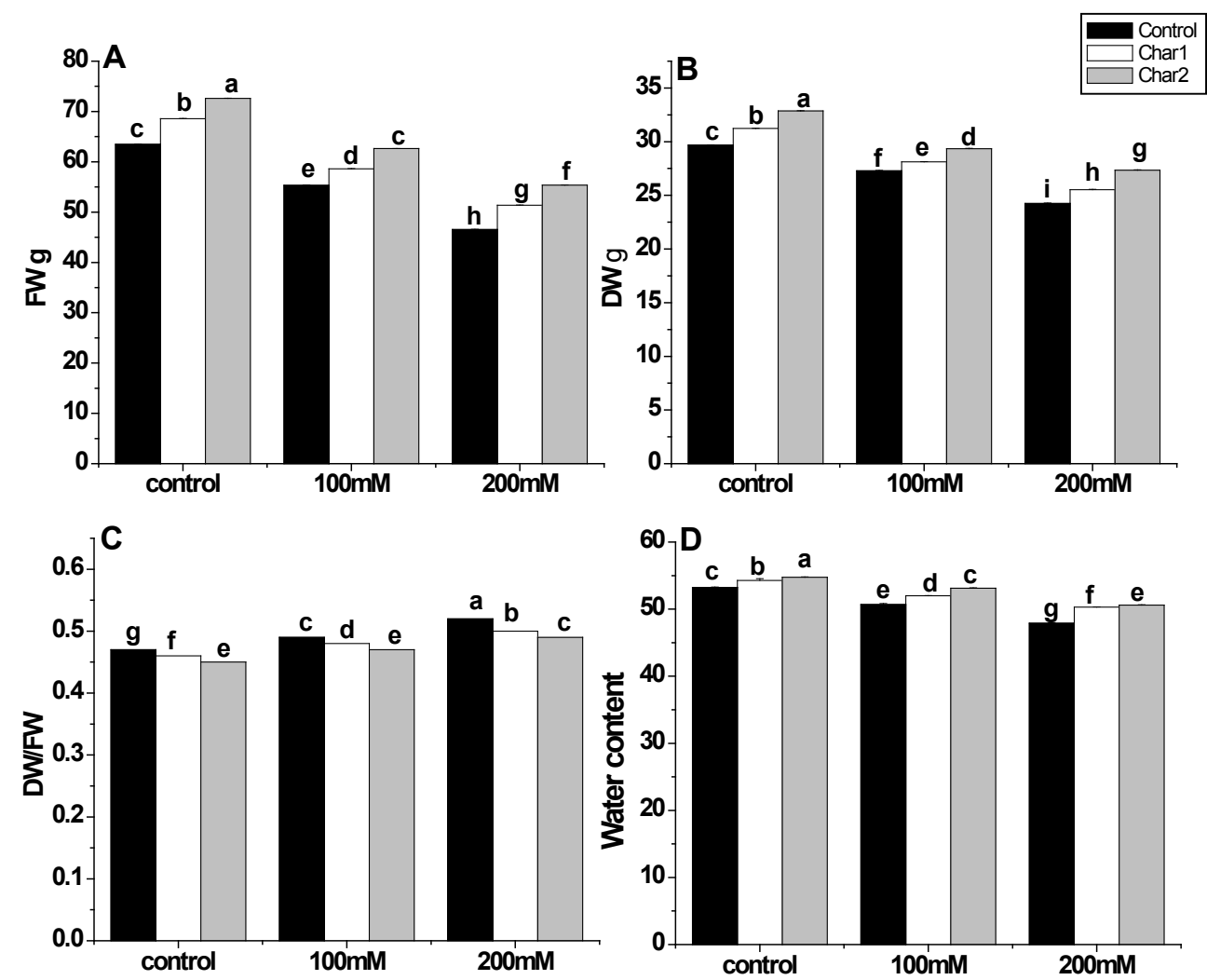

Fig. 2. Different performance parameters of volkamer lemon seedlings treated with 0,100 and $200 \mathrm{mM} \mathrm{of} \mathrm{NaCl}$ exposure for 90 days. A, B, C and D refers to Fresh weight (FW), Dry weight (D.W), DW/FW and Water content, respectively. Data indicated means $(n=5 \pm S E)$. Different letters indicated significant differences at $\mathbf{p}<\mathbf{0 . 0 5}$.
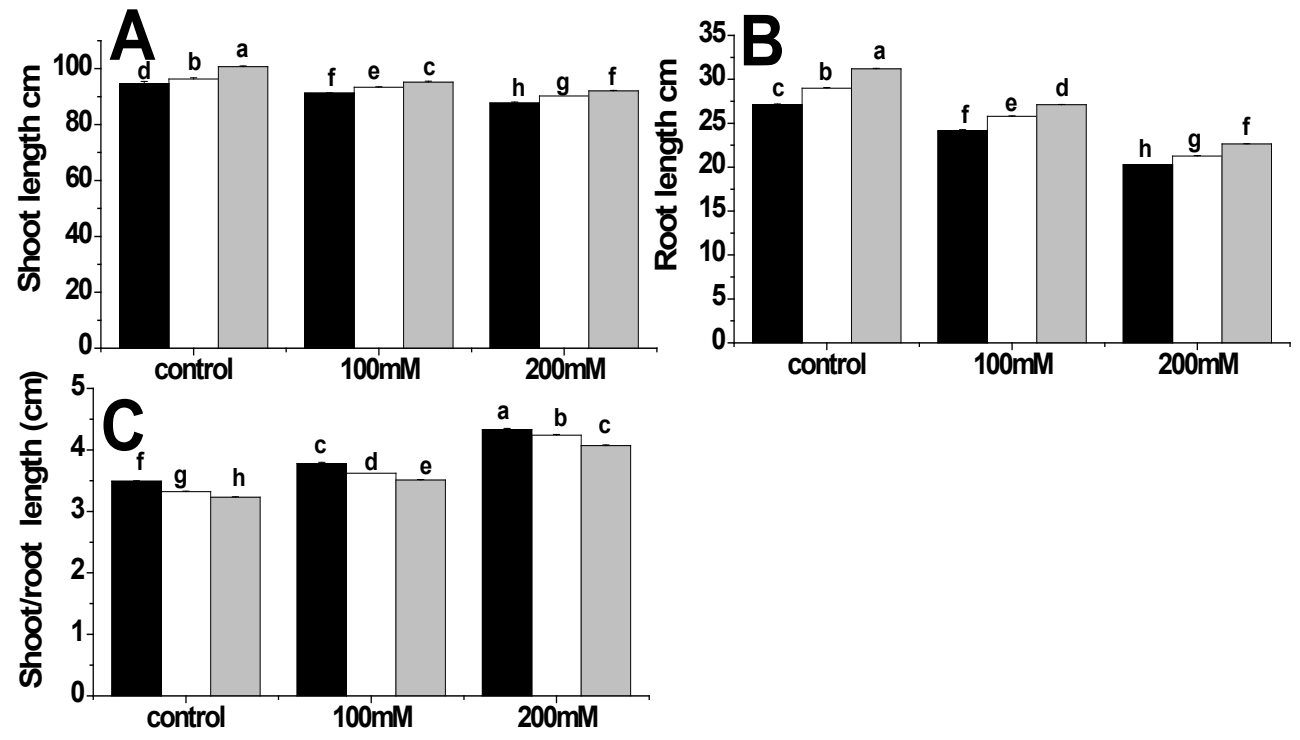

Fig. 3. Different performance parameters of volkamer lemon seedlings treated with 0,100 and $200 \mathrm{mM} \mathrm{of} \mathrm{NaCl}$ exposure for 90 days. $\mathrm{A}, \mathrm{B}, \mathrm{C}$ and $\mathrm{D}$ refers to shoot length, shoot width, root length, root width and shoot/ root length, respectively. Data indicated means $(n=5 \pm S E$ ). Different letters indicated significant differences at $\mathrm{p}<0.05$.

Egypt. J. Hort. Vol. 45, No. 2 (2018) 
Interestingly biochar enhanced shoot length in free salts treatment compared to control (zero biochar) (Fig. 3. A). Similarly, root length showed clearly lower growth in response to salt stress compared to control (Fig. 3. B). Moreover, biochar applications significantly decreased the inhibition growth of root increase length and width due to salt exposure compared to control (Fig. 3. B). Furthermore, salt exposure increased shoot/root length increasing compared to control (Fig. 3, C). On the other hand, biochar applications significantly decreased the impaired effects on shoot growth under salinity stress (Fig. 3, C).

\section{Biochemical parameters}

Relative chlorophyll content(RCC) significantly decreased after salt exposure in comparison with control (Fig. 4, A). In general, adding biochar enhanced RCC regardless salt applications (Fig. 4, A). On the contrary, proline content showed significant increments at all applications of salt levels compared to control (Fig. 4, B). However, proline accumulation was significantly decreased after biochar addition in both salt applications and control treatments (Fig. 4, B). Similarly electrolyte conductivity (EC) data exhibited same directions as proline content (Fig. 4, C).

\section{Nutrient uptake}

The uptake of N, P and K showed significant impaired due to salt exposure compared to control (Fig. 5. A, B, C). On the other hands, biochar applications significantly alleviate the inhibition of nutrient uptake due to salt exposure (Fig. 5. A, B, C). Whereas salinity treatments resulted in greater increasing $\mathrm{Na}^{+}$accumulation compared to control (Fig. 5, D).

While biochar addition showed significant reduction in $\mathrm{Na}^{+}$accumulation in the absence or presence of salt compared to control (Fig. 5, D). Furthermore $\mathrm{K}^{+} / \mathrm{Na}^{+}$showed clearly significant reduction at salt application in comparison with control (Fig. 5, E). Whereas biochar additions has been showed significant increase in $\mathrm{K}^{+} / \mathrm{Na}^{+}$in the absence or presence of salt compared to control (Fig. 5, E).

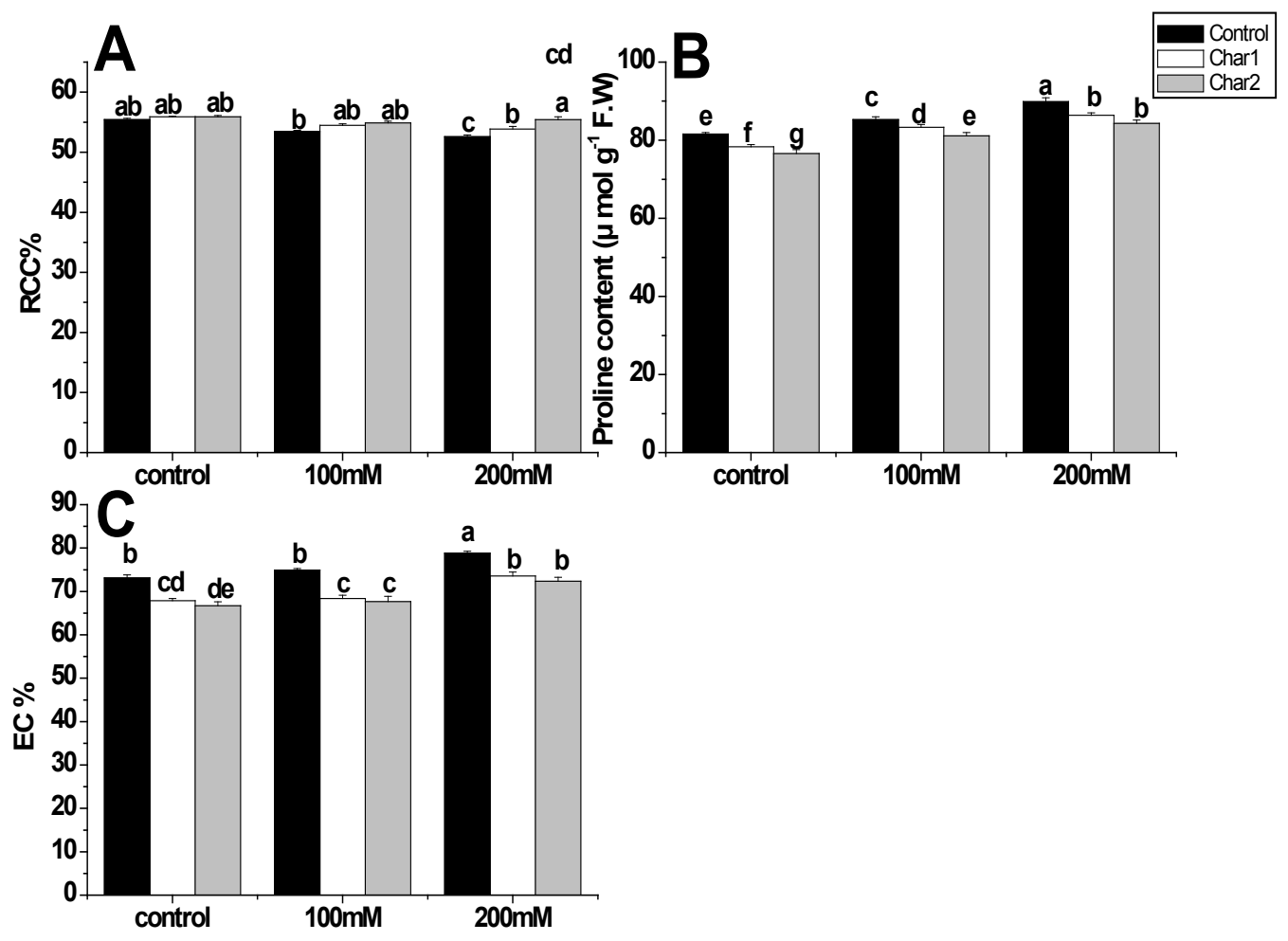

Fig. 4. Biochemical parameter content in volkamer lemon leaves treated with 0,100 and $200 \mathrm{mM}$ of $\mathrm{NaCl}$ exposure for 90 days. A, B and $\mathrm{C}$ refers to relative chlorophyll content (RCC), proline and electrolyte conductivity (EC), respectively. Data indicated means $(n=5 \pm S E)$. Different letters indicated significant differences at $\mathbf{p}<\mathbf{0 . 0 5}$. 

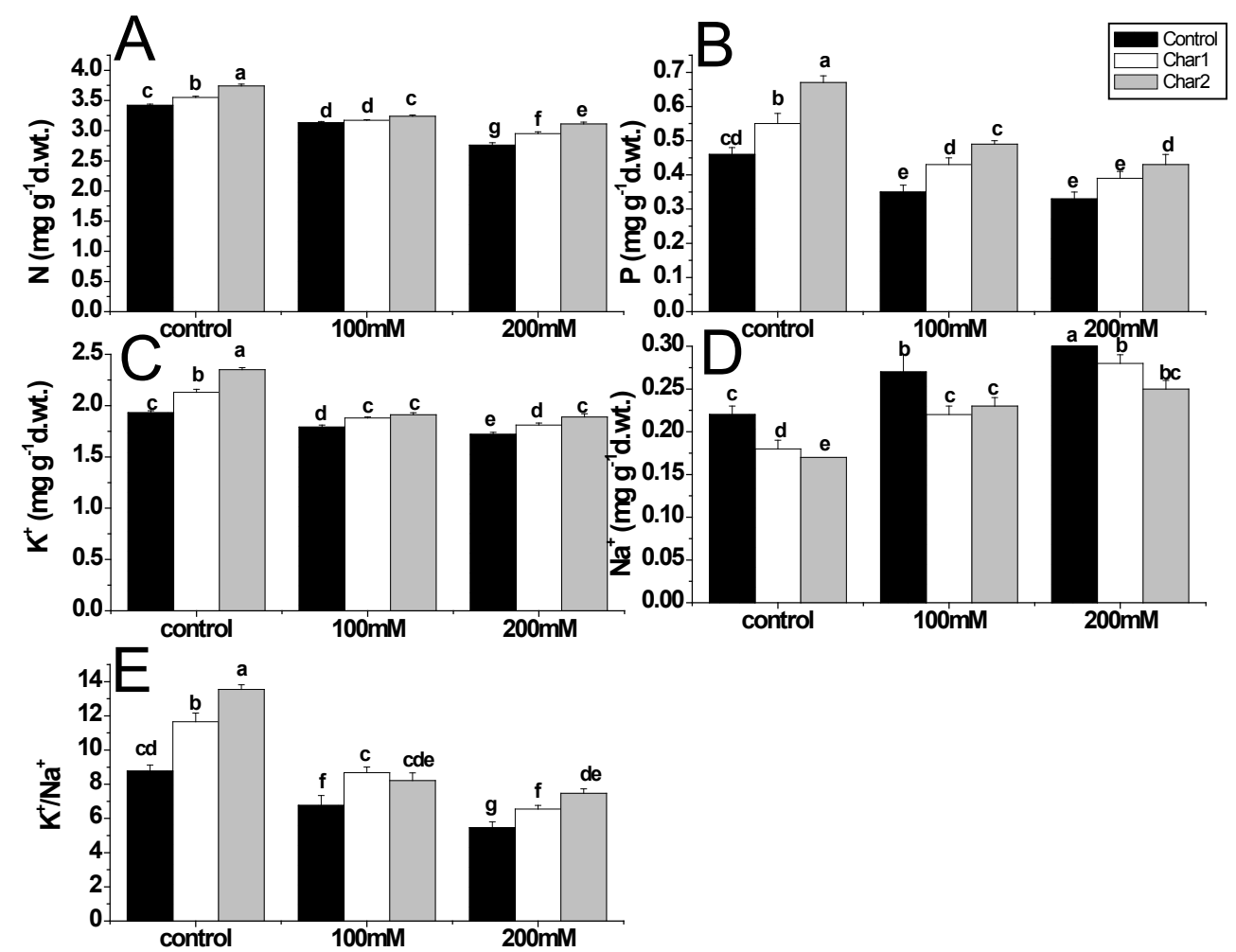

Fig. 5. Cation content in volkamer lemon leaves treated with 0,100 and $200 \mathrm{mM}$ of $\mathrm{NaCl}$ exposure for 90 days. A, B, C, D and E refers to (N) Nitrogen, (P) Phosphorus, (K+) Potassium, (Na+) Sodium and (K+/Na+) Potassium: sodium ratio, respectively. Data indicated means $(n=5 \pm \mathrm{SE})$. Different letters indicated significant differences at $\mathbf{p}<\mathbf{0 . 0 5}$.

\section{Discussions}

In general soil salinity causes a reduction in plant biomass (Munns, 2002). Inhibition in plant growth due to salinity is related to osmotic stress (Munns and Tester, 2008). Ali et al. (2017) in review article reported that plant performance and yield are severely decreased by salt stress. In the present study both of salt levels (100 and $200 \mathrm{mM} \mathrm{NaCl}$ ) reduced biomass growth with respect to the corresponding controls. Whereas results clearly indicate that biochar application alleviate the negative effects of salinity stress on plant performance, as well as addition of biochar alone in the absence of salinity improved plant behavior. To handle this in details, the results of the present study exhibited that biochar application improved leaf area of the exposed plants to salt stress (Fig. 1. A, B). These results were found to be in harmony with (Van Zwieten et al., 2010 and Thomas et al., 2013). Additionally, stimulating effects of biochar on biomass growth (Fig. 2. A, B), e.g., fresh weight (FW) and dry

Egypt. J. Hort. Vol. 45, No. 2 (2018) weight (DW) after salt exposure were found to be in close agreement with many previous works (Van Zwieten et al., 2010, Dharmakeerthi et al., 2012, Drake et al., 2016). The DW/ FW is considered an indicator of the effect of salt on biomass growth (Niazi et al., 1992). In addition, water content is related to FW/DW and it was expected that biochar application reduced DW/ $\mathrm{FW}$, subsequently increasing water content under saline conditions (Fig. 2. C, D). This is dependant on the fact that biochar introduced high surface area per unit mass, subsequently increasing water absorption (Atkinson et al., 2010, Laird et al., 2010). Similar results, where significant loss of biomass in lemon balm due to low water content has been reported (Ozturk et al., 2004, Farahany et al., 2009 and Manukyan, 2011). Similar stimulation of shoot and root lengths as related to biochar application in salt treatments (Fig. 3 . A, B) was found in agreement with other studies which stated that biochar application on sugarcane and Acer Mono under salt condition leads to the increase of shoot and root length and general root 
system morphology (Razaq et al., 2017 and Yang et al., 2015). The increasing of shoot/root length is reflecting the rapid inhibition of shoot growth while root growth is maintained, suggesting that biochar somehow reduce the inhibition of shoot growth in saline condition (Fig. 3. C, Flórez et al., 2008, Rasmuson \& Anderson, 2002 and Zheng et al., 2012). Chlorophyll content is an alternative parameters which indicates the effect of salt stress on leaves injury which maybe not showing visible symptoms such chlorosis or necrosis. Biochar application inhibited salt effect on chlorophyll content suggesting a role of biochar against chlorophyll degradation (Fig. 4. A, Akhtar et al., 2015, Yang et al., 2015 and Zheng et al., 2012). Furthermore, the increase in proline content is important indicator to salt stress where free proline is synthesized in cells via protein biosynthesis or metabolism to regulate the osmotic potential in plant cell, subsequently protecting sub-cellular structures and macromolecules from osmotic stress (Ashraf and Foolad, 2007, Chen and Dickman, 2005). Biochar application reduced the increase of proline content after addition to salt treatments (Fig. 4. A, Farhangi-Abriz \& Torabian, 2017 and Lashari et al., 2015). In the same line these data referred to the direct adsorption of ions that causes salinity by biochar due to the reduction of electrolyte conductivity (EC) in biochar treatments under both salt levels (Fig. 4, C). This suggests a role of biochar in preventing damage of cell plasma membrane due to high ions leaking from roots to shoots. Similarly, electrolyte conductivity (EC) as an indicator of membrane stability and stress tolerance in plants has been successfully used (Stevens et al., 2006 and Lopez-Perez et al., 2009, Lashari et al., 2015). Furthermore, the increased plant tissue of nitrogen $(\mathrm{N})$, phosphorous $(\mathrm{P})$ and potassium $\left(\mathrm{K}^{+}\right)$ concentrations (Fig. 5. A, B, C) is related to the increase of nutrients absorption after addition of biochar, as has been previously stated (Atkinson et al. 2010, Barrow 2012, Dharmakeerthi et al., 2012, Joseph et al., 2010 and Yang et al., 2015). Increasing availability of nutrients with biochar applications is related to high surface area per unit mass, subsequently increasing wide range of ions and cations exchangeable capacity, CEC (Atkinson et al., 2010 and Laird et al., 2010). $\mathrm{Na}^{+}$competes with other cations affecting cation uptake, subsequently ion homeostasis (Zhu 2003, Munns \& Tester 2008 and Shabala \& Cuin, 2008). In this context $\mathrm{Na}^{+}$was measured in plant leaves under all treatments (Fig. 5, D). The increase in $\mathrm{Na}^{+}$concentration in leaves following $\mathrm{NaCl}$ treatments is in agreement with other reports on citrus trees (Ruiz et al., 1997, Anjum et al., 2001 and Levy \& Syvertsen, 2004). The results showed that biochar application reduced the accumulation of $\mathrm{Na}^{+}$and showed high increase in $\mathrm{K}^{+} / \mathrm{Na}^{+}$in salt treated plants (Fig. 5. D, E). These results are in agreement with previous study (Akhtar et al., 2015, Ali et al. 2017 and Drake et al., 2016).

\section{Conclusion}

It can be concluded from this study that biochar addition alleviated the negative effects of salt stress on all parameter under investigations. Mixing biochar with media affected salinity enhanced growth parameters, photosynthesis and nutrient uptake, whereas impair $\mathrm{Na}^{+}$uptake, proline content and EC. Depending on the previous finding in this study the author strongly supported the view of using biochar as a promising soil amendment that ameliorate problems associated with salinity stress especially in the fruit nurseries.

\section{Acknowledgment}

I would like to express my sincere gratitude to Tanta University, Egypt for funding and introducing all facilities needed for this study. I sincerely thankful to those all the staff members of Horticulture Department, Faculty of Agriculture, Tanta University, who friendly helped me a lot to achieve this work.

\section{Funding statement}

The present work was partially supported by Faculty of Agriculture, Tanta University, Egypt.

\section{Conflicts of interest}

The author declares that there are no conflicts of interest related to the publication of this work.

\section{$\underline{\text { References }}$}

Abadi, F.G., Mostafavi, M., Eboutalebi, A., Samavat, S. and Ebadi, A. (2010) Biomass accumulation and proline content of six citrus rootstocks as influenced by long-term salinity. Res. J. Environ. Sci., 4, 158165.

Akhtar, S.S., Andersen M.N. and Liu, F. (2015) Residual effects of biochar on improving growth, physiology and yield of wheat under salt stress. Agric. Water Manag., 158, 61-68.

Ali, S., Rizwan, M., Qayyum, M.F., Ok, Y.S., Ibrahim, M., Riaz, M. and Shahzad, A.N. (2017) Biochar soil amendment on alleviation of drought and salt stress in plants: a critical review. Environmental Science and Pollution Research, 1-13.

Egypt. J. Hort. Vol. 45, No. 2 (2018) 
Anjum, M.A., Abid, M. and Naveed, F. (2001) Evaluation of citrus rootstocks for salinity tolerance at seedling stage. Int. J. Agric. Biol., 3, 1-4.

Ashraf, M. and Foolad, M. (2007) Roles of glycine betaine and proline in improving plant abiotic stress resistance. Environ. Exp. Bot., 59,206-216

Atkinson, C., Fitzgerald J. and Hipps N. (2010) Potential mechanisms for achieving agricultural benefits from biochar application to temperate soils: a review. Plant and Soil, 337, 1-18.

Barrow, C. (2012) Biochar: potential for countering land degradation and for improving agriculture. Applied Geography, 34, 21-28.

Bates, L.S., Waldren, R.P. and Teare, I.D (1973) Rapid determination of free proline for water-stress studies. Plant Soil, 39, 205-207.

Brito, M.E.B., de Brito, K.S.A., Fernandes, P.D., Gheyi, H.R., Suassuna, J.F., dos Santos Soares Filho, W. and Xavier, D.A. (2014) Growth of ungrafted and grafted citrus rootstocks under saline water irrigation. African Journal of Agricultural Research, 9 (50), 3600-3609.

Brito, M.E.B., Soares Filho, W.S., Silva, L. A. and Fernandes, P. D. (2016) Gas Exchange and fluorescence of citrus rootstocks varieties under saline stress. Revista Brasileira de Fruticultura, v. 38, n. 2, e-951, http://dx.doi.org/10.1590/010029452016951

Chen, C. and Dickman, M.B. (2005) Proline suppresses apoptosis in the fungal pathogen Colletotrichum trifolii. Proc. Natl. Acad. Sci. U.S.A., 102, 34593464.

Cottenie, A., Verloo, M., Kiekens, L., Velgle, G. and Amerlynuck, R. (1982) Chemical Analysis of Plant and Soil, 43- 51. Laboratory of Analytical and Agroch. State Univ. of Belgium,Gent.

Davies, F.S. and Albrigo, L.G. (1999) Citrus. Acribia Publisher, Zaragoza, Spain, Pages, 296.

Dharmakeerthi, R.S., Chandrasiri, J.A.S. and Edirimanne, V.U. (2012) Effect of rubber wood biochar on nutrition and growth of nursery plants of Hevea brasiliensis established in an Ultisol. Springer Plus, 1 (1), 84.

Drake, J.A., Cavagnaro, T.R., Cunningham, S.C., Jackson, W.R. and Patti, A.F. (2016) Does biochar improve establishment of tree seedlings in saline sodic soils? Land Degradation \& Development, 27 (1), 52-59.

Egypt. J. Hort. Vol. 45, No. 2 (2018)
Duncan, D. B. (1955) Multiple range and multiple "F" testes. Biometrics, 11, 1-42.

Fadli, A., El Aymani, I., Chetto, O., Boudoudou, D.,Talha, A., Benkerane, R. and Benyahia, H (2015) Screening of six citrus rootstocks for salt tolerance at emergence and early seedling stage, International Journal of Recent Scientific Research, 6 (12),7672-7678.

Farahany, H.A., Valadabadi, S.A., Daneshian, J. and Khalvati, M.A. (2009) Evaluation on changing of essential oil of balm (Melissa officinalis L.) under water deficit stress conditions. J. Med. Plants Res., 3, 329-333.

Farhangi-Abriz, S. and Torabian, S. (2017) Antioxidant enzyme and osmotic adjustment changes in bean seedlings as affected by biochar under salt stress. Ecotoxicology and environmental safety, 137, 64-70

Flórez, S. L., Lasprilla, D. M., Chaves B., Fischer, G. and Magnitskiy, S. (2008) Growth of lulo (Solanum quitoense Lam.) plants affected by salinity and substrate. Revista Brasileira de Fruticultur, 30 (2), 402-408

Hartmann, H.T. and Kester, D.E. (1983) Plant propagation. 4th Edition by Prentice-Hall, Inc. Englewood Cliffs, New Jersy.

Hepaksoy, S. (2000) Effect of salinity on citrus. $J$. Aegean Agric. Res. Inst. Turk., 10 (1), 52-72.

Ishigaki, K., Fujie, H. and Suzuki, K. (1990) The effect of the soil amendment materials with charcoal and wood vinegar on the growth of citrus, tea plant and vegetables. TRA Report, 107-120

Jackson, M.L. (1958) Soil Chemical Analysis, Englewood Cliffs, NJ: Prentice-Hall.

Joseph, S., Camps-Arbestain, M., Lin, Y., Munroe, P., Chia, C., Hook, J., Van Zweiten, L., Kimber, S., Cowie, A., Singh, B., Lehmann, J., Foidl, N., Smernik, R. and Amonette, J. (2010) An investigation into the reactions of biochar in soil. Australian Journal of Soil Research, 48, 501-515.

Laird, D., Fleming, P., Wang, B., Horton, R. and Karlen, D. (2010) Biochar impact on nutrient leaching from a Midwestern agricultural soil. Geoderma, 158 (3), 436-442.

Lashari, M. S., Ye, Y., Ji, H., Li, L., Kibue, G. W., Lu, H. and Pan, G. (2015) Biochar-manure compost in conjunction with pyroligneous solution alleviated salt stress and improved leaf bioactivity of maize 
in a saline soil from central China: a 2-year field experiment. Journal of the Science of Food and Agriculture, 95 (6), 1321-1327.

Lea-Cox, J.D. and Syvertsen, J.P. (1993) Salinity reduces water use and nitrate $-\mathrm{N}$ - use efficiency of citrus. Ann. Bot., 72, 47-54

Lehmann, J. and Joseph, S. (2009) Biochar for environmental management: science and technology. Earthscan, London.

Levy, Y. and Syvertsen, J. (2004) Irrigation water quality and salinity effects in citrus trees. In: Horticultural Reviews, Volume 30, Janick, J. (Ed.), Chapter 2, John Wiley and Sons, New York, USA, ISBN-13, 37-82.

Lindaya, M.S. (2008) Citrus Fruits: Biology, Technology and Evaluation. Academic Press, San Diego, California, USA.

López-Pérez, L., Martínez-Ballesta, M.D.C., Maurel, C. and Carvajal, M. (2009) Changes in plasma membrane lipids, aquaporins and proton pump of broccoli roots, as an adaptation mechanism to salinity. Phytochemistry, 70, 492-500.

Manukyan, A. (2011) Effect of growing factors on productivity and quality of lemon catmint, lemon balm and sage under soilless greenhouse production: I. Drought stress. Med. Aromat. Plant Sci. Biotechnol., 5, 119-125.

Monneveux, P.H. and Nemmar, M. (1986) Contribution à l'étude de la résistance à la sécheresse chez le blé tendre (Triticum aestivum L.) et chez le blé dur (Triticum durum Desf.): Etude de l'accumulation de la proline au cours du cycle de développement. Agronomie, 6 (6), 583-594

Munns R. and Tester M. (2008) Mechanisms of salinity tolerance. Annu. Rev. Plant Biol., 59, 651-681

Najafian, S., Rahemi, M. and Tavallali, V. (2008) Effect of salinity on tolerance of two bitter almond rootstocks. Am. Eurasian. J. Agric. Environ. Sci., 3, 264-268.

Naver, E.M., Roistacher, C.N. and Labanauskas, C.K. (1986) Growing citrus in modified UC potting mixtures. Calif. Citrog, 53, 456-461.

Niazi, M.L.K., Mahmood, K., Mujtaba, S.M. and Malik, K.A. (1992) Salinity tolerance in different cultivars of barley (Hordeum vulgare L.). Biologia Plantarum, 34, 456-465
Ozturk, A, Unlukar, A, Ipek, A and Gurbuz, B. (2004) Effects of salt stress and water deficit on plant growth and essential oil content of lemon balm (Melissa officinalis L.). Pak J Bot., 36,787-792.

Page, A.L. (1982) Method of Soil Analysis, Part 2, Chemical and Microbiological Properties, $2^{\text {nd }}$ ed., American Society of Agronomy, Inc and Soil Science Society of America, Inc., Publisher, Madison, Wisconsin USA.

Rasmuson, K.E. and Anderson, J.E. (2002) Salinity affects development, growth, and photosynthesis in cheatgrass. Journal of Range Management, 55, 80-87

Razaq, M., Shen, H.L., Sher, H. and Zhang, P. (2017) Influence of biochar and nitrogen on fine root morphology, physiology, and chemistry of Acer mono. Scientific reports 7(1), 5367.

Ruiz, D., Martinez, V. and Cerda, A. (1997) Citrus response to salinity: Growth and nutrient uptake. Tree Physiol. 17, 141-150.

Shabala, S. and Cuin, T.A. (2008) Potassium transport and plant salt tolerance. Physiol Plant, 133, 651669

Snedecor, G. and Cochran, W.G. (1980) Statistical Methods, $7^{\text {th }}$ ed., Iowa State Univ. Press. Amer. Iowa,USA, pp.507.

Stevens, J., Senaratna, T., Sivasithamparam, K. (2006) Salicylic Acid induces salinity tolerance in Tomato (Lycopersicon esculentum cv. Roma): Associated Changes in Gas Exchange, Water Relations and membrane stabilisation. Plant Growth Regul, 49, $77-83$.

Thomas, S., Frye, S., Gale, N., Garmon, M., Launchbury, R., Machado, N., Melamed, S., Murray, J., Petroff, A. and Winsborough, C. (2013) Biochar mitigates negative effects of salt additions on two herbaceous plant species. Journal of Environmental Management, 129, 62-68.

Tripathy, J.N., Zhang, J., Robin, S., Nguyen, T.T. and Nguyen, H.T. (2000) QTLs for cell membrane stability mapped in rice (Oryza Sativa L.) under drought stress. TAG, 100, 1197-1202

Van Zwieten, L., Kimber, S., Morris, S., Chan, K.Y., Downie, A., Rust, J. and Cowie, A. (2010) Effects of biochar from slow pyrolysis of papermill waste on agronomic performance and soil fertility. Plant and soil, 327(1-2), 235-246 
Weggler, K., Carney C. and Stone, C. (2008) Effect of fertilizer and water supply on the growth, nutrient status and photochemical efficiency of Eucalyptus pilularis seedlings in a phosphorus-deficient soil. Australian Forestry, 71, 54-63.

Yadav, S., Irfan, M., Ahmad, A. and Hayat, S. (2011) Causes of salinity and plant manifestations to salt stress: A review. J. Environ. Biol., 32, 667-685.

Yang, L., Liao, F., Huang, M.,Yang, L. and Li, Y. (2015) Biochar improves sugarcane seedling root and soil properties under a pot experiment. Sugar Tech., 17(1), 36-40
Zheng, Y. H., Li, X., Li, Y. G., Miao, B. H., Xu, H., Simmons, M. and Ang, X. H. (2012) Contrasting responses of salinity-stressed salt-tolerant and intolerant winter wheat (Triticum aestivum L.) cultivars to ozone pollution. Plant Physiology and Biochemistry, 52, 169-178

Zhu, J.K. (2003) Regulation of ion homeostasis under salt stress. Curr. Opin. Plant Biol., 6, 441-445.

تأثثرالبيوشارعلى النمو والقياسات البيوكيماوية ومحتوى العناصر الغذائية لليمون الفولكاماريانا تحت الظروف الملحية

عاطف مصطفى محمد النشرتى أبو عجيلة

قسم البساتين - كلية الزراعة - جامعة طنطا ـ طنطا - مصر.

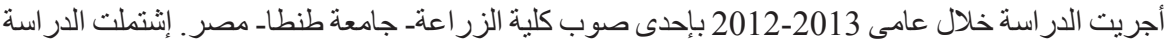

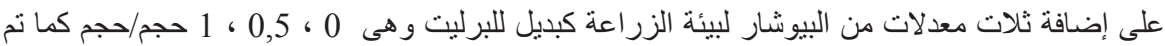

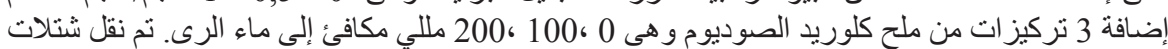

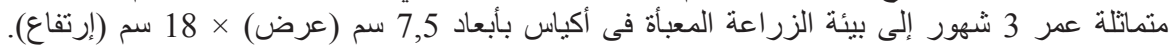

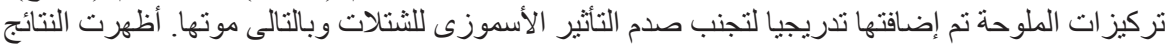

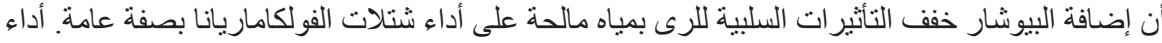

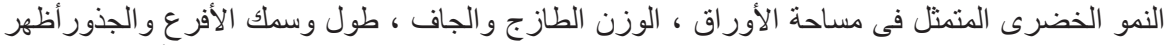

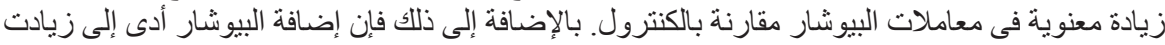

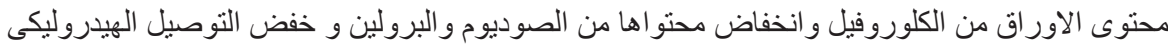

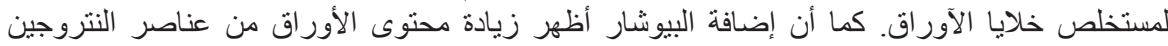

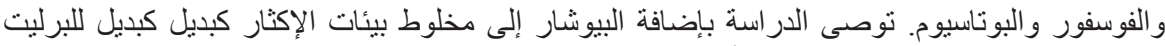
بمعدل 1 حجم/حجم. تؤكد الدراسة على أن تطبيقات البيوشار لله دور و اعد على تخفيف الآثار السلبية للإجهاد للإليات 